\title{
Yayın Değerlendirme
}

\section{Sinan Pașa Maârif-nâme Kitabı Üzerine ${ }^{1}$}

\section{Ömer GÖK ${ }^{2}$}

Klasik Türk edebiyatı denince şiirin ve şairin akla geldiği bir ortamda nesir alanında temayüz etmiş; öyle ki güçlü seci üslubu ile yeni bir çı̆̆ır açmış; Devlet-i Âliye'nin en üst makamlarında bulunmuş; yeri geldiğinde padişahı, vezirleri eleştirmekten imtina etmemiş bir şahsiyet: Sinan Paşa. Daha ziyade Tazarru-nâme adlı eseri ile tanınan Sinan Paşa'nın bir diğer önemli eseri ise Maârif-nâmédir. Uzun yıllar ilmî neşri bulunmayan Maârif-nâme, 2013 yılında Atatürk Kültür Merkezi Başkanlığı Yayınları arasından çıkmıştır. Günümüzde "hocaların hocası" vasfı yakıştırılan nadir hocalardan olan Mertol Tulum tarafından yayıma hazırlanan Maârif-nâme, "Özlü Sözler ve Öğütler Kitabı” alt başlı̆̆ıyla okuyucuya sunulmuştur. Bir nevi irfan ve nasihat madeni niteliği taşıyan eser için bu alt başlık oldukça isabetli olmuştur. Nitekim irfanî geleneğin ve tasavvufî neşvenin Sinan Paşa'da bulduğu insiyak, eserin tümüne sirayet etmiştir.

Maârif-nâme’ye gelmeden evvel müellifi hakkında biraz malumat vermek yerinde olacaktır. Sinan Paşa'nın doğum yeri ve tarihi ile ilgili farklı kaynaklarda farklı bilgiler mevcuttur. Ancak doğum tarihi ile ilgili Mecdî Efendi'nin verdiği 1441 (H. 845) tarihi; doğum yeri ile ilgili ise Bursa şehri genel kabul görmektedir. Dedesi Sivrihisar kadısı Celâleddin Efendi, babası Hızır Bey'dir. Anne tarafindan dedesi de devrin önde gelen âlimlerinden Molla Yegân'dır. Hizır Bey, bizzat Fatih Sultan Mehmed tarafindan İstanbul'a davet edildiğinde oğlu Yûsuf Sinaneddîn henüz 13-14 yaşlarındadır. İstanbul'a geldiklerinde bir taraftan dedesi Molla Yegân'ın ilim meclislerine devam edip burada Molla Gürânî, Molla Kırımî, Hoca-zâde Muslihuddin ve Molla Hüsrev gibi devrin meşhur âlimlerinin rahle-i tedrisinden geçmiş; diğer yan- 
dan İstanbul'un ilk kadısı olan babası Hızır Bey'in etrafındaki ilim erbabıyla meşverette bulunma imkânını yakalamıştır. Bulunduğu muhitler vesilesiyle ilim tahsilinde genç yaşta mertebe alan Paşa, Fatih Sultan Mehmed'in isteği üzerine saray hocalığına kadar yükseltilmiştir. Öyle ki bu vazifesinden ötürü kendisine "Hâce-i Sultânî" diye hitap edilmiştir. İlmî payelerinin yanı sıra kendisinin Paşa olarak anılmasında baş etmenlerden olan vezir-i azamlığ saray içindeki çekişmelerden ötürü pek kısa (bir yıldan daha az) sürmüştür. Paşa, bu dönemde yaşadığı sıkıntılara dair Maârif-nâméde yer yer göndermelerde bulunmuştur. Sinan Paşa'nın doğduğu yer gibi vefat ettiği yer konusunda da ihtilaf vardır. Ancak vefat tarihi 1486 (H. 891) yılı olarak kayıtlara geçmiştir.

Sinan Paşa'nın tespit edilebilen on bir civarı Arapça (çoğunluğu şerh ve haşiye), üç de Türkçe eseri bulunmaktadır. Burada Arapça eserlerini saymayacağı ancak Türkçe telif eserleri şunlardır: 1. Tazarru-nâme, 2. Maârif-nâme, 3. Tezkiretü'l-Evliyâ. Üç eserde hâkim olan tasavvuf ve hikmet merkezli söyleyiş ise Paşa'nın bu yönünün daha iyi anlaşabilmesine imkân sağlamaktadır. Söz konusu eserlerin bir başka ortak yönü de Sinan Paşa'nın daha olgun dönemlerine rastlamaları ve bu dönemde payitahtta II. Bayezid'in olmasıdır.

Maârif-nâme üzerine ilk çalı̧̧ma yapan araştırmacı İsmail Hikmet Ertaylan olmuştur. Ertaylan, Maârif-nâmènin bir nüshasının tıpkıbasımı ile Sinan Paşa ve eserlerini ele aldığı çalışmasını 1961 yılında yayımlamışır. Bundan sonra eser üzerine ilk kez derinlemesine eğilen ise bu eserin de müellifi olan Mertol Tulum olmuştur. Tulum, "Maârif-nâme - Metin ve ki'li Birleşik Cümleler Üzerinde Bir Araştırma" başlıklı doçentlik tezinde eserin ilk kez ilmî neşrini gerçekleştirmiştir. 1979 y1lında yapmış olduğu bu çalışmanın neden bugüne kadar geniş okuyucu kitlelerine ulaşmadığını da yine kendisi eserin "Sunuş" unda açıklıyor: "ne yazık ki, çeşitli engeller yüzünden bugüne kadar bu çalışmamı yayımlayamadım. Aslında asıl engel, şu ana düşüncemdi: büyük yazarın üç Türkçe eserini de günümüz Türkçesine aktarılmış metinleriyle birlikte sunmak, böylece bu eşsiz nesir ustasını bugünün geniş okuyucu kesimiyle tanıştırmak" (2013: XXI). Mertol Tulum bu emeli ilk olarak Tazarru-nâme ile gerçekleştirmiştir. Sıra Mâ̂rif-nâme’ye gelmiştir. İşte elimizdeki bu eser, hocanın arzu ettiği tertibatta olup eserin Latin harflerine aktarılmış hâli ile dil içi çevirisi yan yana olacak şekilde hazırlanmıştır. Bu sayede bugünün okuru için de manaya erişmenin önündeki en büyük engellerden biri giderilmiştir. 
Eser, "Sunuş", "Metin” ve "Açılamalar” diye üç bölüme ayrılmıştır. Sunuş'ta yazar, Mâ̂rif-nâme hakkında bu çalışmaya kadar ciddi bir çalışma yapilmadığından bahisle eseri nasıl tespit ettiğini ve ne zaman hazırlamaya karar verdiğini; eserin hazırlanış serüvenini ve içeriğinde okuyucunun neler bulabileceğini anlatmıştır. Tulum, "Eserin büyük bir kısmını oluşturan aforizmalardan her biri, erdemliliğin ve ahlâk değerlerinin ne, bu değerlere bağlı olmanın nasıl olduğunu bilmek isteyen herkes için, her an hatırda tutulması, hafıza kartına yüklenmesi istenecek ilkeler hükmündedir” (2013: XXIII) diyerek okuyucunun bu eserde ne bulabileceğine dikkat çekmektedir.

Kitabın esas bölümü ise elbette "Metin” bölümüdür. Bu bölümünde metnin dilinin güncelleştirilmiş / sadeleştirilmiş hâlinin de verilmiş olması çalışmanın özgün yanıdır. Hem o günkü yazı dilinin görülmesini hem de bugünkü okuyucunun manaya daha çabuk vâkıf olmasını sağlayacak bu usul, Tulum'un alana sunduğu önemli bir katkıdır. Bu bölüm klasik metinlerde görülen "Münacat”, "Na't”, "Na'tü'l-Aşereti'l-Mübeşşere”, “Na'tü'l-Hulefâi'l-Erbaa” ve "Sebeb-i Telif” bölümleriyle başlıyor. Bunlara metnin giriş bölümü diyebiliriz.

Girişten sonra 145 başlık altında Sinan Paşa'nın ilim ve marifet deryasından süzülen nasihat ve sözleri okuyucuyu bekliyor. Burada işlenen konulardan bazıları şunlardır: dünyayı ve içinde olanları kötüleme, gerçek marifet üzerine, öfkeyi sindirmeye özendirme, sadaka vermeye arzu uyandırma, Kur'an-1 Kerîm’e övgü, zamane adamlarına yergi, kanaate övgü, güzel ahlâkı özendirme, cömertlik ve yardım, dünyanın gelip geçiciliği, bilgi ve akla övgü, susmaya övgü, çok konuşmaya yergi, sahte şeyhleri kötüleme, zulme yol vermeme, gönülleri görüp gözetme, büyük Tanrı dostlarına övgü vb. Bunlardan başka müellif ara ara işlediği konulara uygun hikâyeler dile getirmiş; bazen de "Tevbîhât" ve "Tenbîhât" başlikları altında paylama ve uyarılarda bulunmuştur. Rahatlıkla söylenebilir ki eser baştan sona nefis terbiyesi hususunda birtakım sorulara cevaplar vermekte; bunun yanı sıra iyi bir insan, iyi bir müminde bulunması gereken vasıfları açıklamaktadır.

Sinan Paşa'nın eseri, gelenekte olduğu gibi "Hatime" bölümü ile sona eriyor. Burada eseri bitirebildiği için Allah'a hamd eden müellif, bundan sonra kaleme almayı düşündüğü evliyalar tezkiresi için de Allah'a niyaz etmektedir. Sinan Paşa burada Feridüddin Attar'ın yazdığ Tezkire-i Evliyầya atıfta bulunarak onu "gerçeğe ulaşma yolunda çaba gösterenlerin sultanı" olarak anar ve yazmayı düşündüğü esere onun ilham olacağını ifade eder. 
Mertol Tulum, "Metin" bölümünün sonuna ayrıca "Açıklamalar" başlığıyla bir bölüm daha eklemiştir. Tulum bu bölümde metin içinde geçen başta din ve tasavvuf olmak üzere dil, edebiyat, astronomi ve gelenekteki daha birçok alana ait kavramın izahını yapmıştır. Yaptı̆̆ı bu işi de "eserin ayrıntılı olarak açıklanmasından, yani şerhinden çok da ayrı bir iş sayılmaz" diyerek özetlemiştir (2013: 788). Okuyucu için metinde muğlak kalan yerlerin anlaşılmasında ya da metne daha hâkim olma noktasında bu bölüm oldukça faydalı olmuştur.

Sinan Paşa'nın bundan yaklaşık beş yüz yıl önce kaleme aldığı Maârifet-nâme özü itibariyle bugün hâlâ tazeliğini korumakta, çağımızın insanına manevi reçeteler sunmaktadır. Bunun için eserin gün yüzüne çıkması ve daha geniş bir okuyucu kitlesine ulaşması için Mertol Tulum'un gösterdiği çaba takdire şayandır. Aynı şekilde bu kıymetli eserin yayımını üstlenen Atatürk Kültür Merkezi Başkanlığı da büyük bir teşekkürü hak ediyor. 